\title{
The Relationships Between the Vocational Education Training Providers and Enterprises: Theory and Practice
}

\author{
Vi Hoang Dang \\ Namdinh Vocational College, Vietnam, University of New England, Australia \\ Email: hdang2@myune.edu.au
}

Received: 29-02- 2016

doi:10.7575/aiac.ijels.v.4n.2p.47
Accepted: 17-04-2016

URL: http://dx.doi.org/10.7575/aiac.ijels.v.4n.2p.47
Published: 30-04-2016

\begin{abstract}
The importance of the relationships between industry and academia is stressed by strategists, politicians, Vocational Education Training (VET) policy makers, and industrial planners. Industry without knowledge surely dies, and knowledge without application of that knowledge is valueless. This paper focuses on the relationships between the VET providers and industries. More specifically, the purpose of this paper is (1) to discuss the factors which enhance or constrain the strategic partnership, (2) to present the experiences of this relationship in the developing and developed countries, (3) to propose a model that links the two institutions, the VET providers and industries, in the Vietnamese context.
\end{abstract}

Keywords: The VET provider-industry relationship, theory, practice, and Vietnam

\section{Introduction}

The strategic partnership between VET school and industry is a core value of the VET sector that increases the quality of VET outcomes and meets the requirements of society and industry. Depending on the culture, political issues, and economic status of each nation, so the model of the links between VET providers and industries is different. The big question mark is how the linkages work effectively, and what the roles of key stakeholders, such as the government, VET providers, and industries, in these linkages are. Therefore, firstly, this paper begins with a review on how to form the strategic partnerships among key stakeholders in the VET sector and a discussion what factors enhance or constrain the strategic partnerships. Secondly, the models of relationships between VET providers and industries of the developing and developed countries in the world are described as examples for discussion. Lastly, based on these models, recommendations for boosting the comprehensive cooperation between VET schools and industries in Vietnam are proposed.

\section{Shaping the strategic partnerships between stakeholders in VET}

The term strategic partnership has gradually emerged to describe a new form of governance. According to Mitchell (1998), "a strategic partnership involves some shape of formal agreement between two (a bilateral partnership) or more (a network partnership) parties that have agreed to share finance, skills, information, and/or other resources in the pursuit of common goals."

\subsection{How are the stakeholders involved?}

According to Mitchell (1998), key stakeholders are involved in three levels of relationship namely the micro, macro and meso level.

Macro level of partnership involves the governmental bodies of a VET system. According to Atchoarena (1999) and Mitchell (1998) there must be strong political ties for forming partnerships in the VET sector in order to connect the link between the working world and the education system. Macro level partnerships may involve government systems, national policies on training and worker representatives all the way to materials donated by businesses.

Meso level partnerships take place in the sector area. According to Mitchell (1998) Meso level partnerships may involve public and private institutions involved in the automobile industry or even donations of big manufacturers to schools involved in the same sector.

Mitchell (1998) argues that the Micro level partnerships take place "between individual firms and public training institutions, and may also involve the local government and public and private training providers, including voluntary agencies"

\subsection{Factors affecting strategic partnerships}

A multitude of factors affect the success of strategic partnerships. However there is consensus as to which issues are important when coming up with ideas regarding strategic partnerships in the VET sector. According to Mitchell (1998), there are three main factors that enhance or constrain the strategic partnership. The first factor involves the economic 
situation, the degree of technological progress, and the extent of private sector development in a context of increased global competition of the given country. The second factor is the strong political commitment required to shape the links with industry. According to Atchoarena (1995), in order to create the appropriate environment for the partnership to develop, it is the government's task to formulate the laws, policies, and mechanisms enabling the stakeholders to take responsibility and participate, not only to defend their own views, but in the best interest of all parties. Strategic issues for which clear legislation are required include access, provision, financing, certification, and social dialogue. The last factor that constrains or enhances the strategic partnership is the involvement of local key stakeholders. They have been seen as the main actors in the vocational education and training field and impact significantly on the skill development of the local workforce (Bünning, Frank, Schnarr, \& Alexander 2007). According to Mitchell (1998), the ever changing local needs can be responded to if partnerships are responsive towards local demand. Sustainable partnerships depend greatly on the power granted by governments to the private sector and the government's degree of control over shared systems with the private sector. Also the strengths and weaknesses of each partner must be taken into consideration at all three levels of partnership in order to make collaborations effective.

\section{Examples of the relationships between the VET providers and industries}

\subsection{Germany - a dual system}

A dual system of vocational education law is implemented in Germany for vocational education and training. This system consists of two parts. In the first part the aim of vocational education is explained in detail. In the second part the places of learning are identified the industrial side, it is company-based vocational training, and on the school side, it is the school-based component. The law in Germany mandates a partnership in which the two learning locations namely; industry and vocational education providers must co-operate.

The responsibility of the Vocational Training Directive Department is to determine the scale and content of an occupation. According to Bünning, Frank, Schnarr and Alexander (2007) vocational schools in Germany have a "curricular remainder function" this adds to general and vocational subjects during vocational training in companies. Students are not required to sign contracts with regard to vocational training with schools but rather the company and depending on part time or full time study students are required to work on site.

\subsection{France - a school-based system}

Vocational training in France involves full time study at vocational schools. Learners in France must choose from four possible pathways after completing their secondary education. The first pathway involves the usual route that leads to university. The second pathway involves studying at a technical school and continuing a technical subject all the way to university. The third pathway involves attending vocational high school in order to be directly prepared for work, leading to a professional qualification. The forth pathway vocational training is provided by the employer and the responsibility of theoretical component is left to education centres so that the school and company share equal responsibility. The student must sign a training contract with the company involved and in return the student will receive a monthly salary usually between $30-80 \%$ of the companies' minimum wage. The duration can vary between 1 to 3 years. This pathway according to Bünning, Frank, Schnarr, \& Alexander (2007) is chosen by a third of French learners enrolled in vocational education.

According to Bünning, Frank \& Schnarr, and Alexander (2007), in France, the relationship between the VET providers and industries is not valued highly because, in the VET system, there is strong centralisation and the government is in charge of all laws governing vocational education and training. However, this relationship makes it easier for the companies to take in students who are prepared for work through the training contract with companies.

\subsection{Great Britain - an industry-based system}

In Great Britain many organizations can issue a national vocational qualification under the governance of the Qualification and Curriculum Authority. The vocational education system in Great Britain is founded on the belief that regardless of the circumstance any person can acquire a vocational qualification. The national vocational qualification is not concerned with the way the qualifications are obtained, rather it focuses on the required qualifications and how one preforms with regard to a specific job.

Programs for these qualifications are based on the principle of combining different learning units without any time restrictions, and the actual skills of the students are assessed. The vocational education and training is conducted by the further education institutions, the VET providers, and the employers. The focus of the Qualification and Curriculum Authority is on the qualifications necessary for specific job rather than on the way the qualification was obtained. As a result there are no partnerships between the vocational education training providers and the industry. Bünning, Frank, Schnarr and Alexander (2007) argue that "In this system, consideration is given to establishing national mechanisms, ensuring a level of autonomy and decentralisation on the local level, considering the characteristics of the private sector, and creating a positive attitude among all partners".

\subsection{South Korea - a contract-based training}

This model involves training required by companies within technical high schools. This model is characterized by a temporary contract between the parties involved namely, the school, company and the student. Certain obligations must be met by the parties involved these include: 
- Contract based training is offered by the company and carried out by a technical high school

- The school and the company agree on the way CBT is implemented

- The contract based training program is designed and carried out by the school

- Students who complete the contract based training are guaranteed employment by the company

- The students must agree along with their parent's permission to work for 2 years with the company after graduation.

In CBT the school must seek and find the company to initiate the partnership it is also in charge of student enrolment. The students will work in the company after completion of CBT. In return the school will receive financial and organisational government support.

\subsection{China}

The national education conference was held in China in 1994, and practice in the workplace combined with studying was found to be crucial to socialist education and so Cooperation between vocational education training institutions and the work industry are essential in improving vocational education training capacity and outcome.

$\mathrm{Wu}$ (2009) describes four main models of cooperation, each is explained below in detail.

\subsubsection{The "Mutual Cooperation between Enterprise and School" model}

This model involves finding an advisable school partner by the enterprise. Thus the enterprise will search for a reputable vocational education training school and make an agreement that clearly states the responsibilities of both the enterprise and the school. This model is beneficial for both enterprises and schools and can aid with the enterprises production process.

\subsubsection{The 'Training by Order' model}

In this model unlike the first model the job of choosing is left to the school and the school must search for a suitable enterprise. The role of the enterprise is to provide funding and equipment and also to be part of the management board at the school. The role of the school is to design training programs and courses to suite the enterprises needs. Once the students graduate they will be involved in paid employment at the enterprise as part of the contract between the school and the enterprise.

\subsubsection{The "Combined School - Factory" model}

In the school-factory model the vocational education training school works together with an enterprise and runs a joint program with the aim of aiding the local economy. Both the school and enterprise profit greatly from this joined venture. In this model the principle of the VET school shares two roles, not only as the head of the school but also as a director for the enterprise. Teachers also play an important role in increasing production in the industry and also increase the schools profits. Students enrolled also receive high recognition by the community and are highly valued by employers in the industry. The school itself is also admired in the community for its high standards of teaching.

\subsubsection{The 'International Cooperation' model}

In the international cooperation model as the name implies is an international cooperation between enterprises and VET providers. Its aim is to improve the standard of teaching and services to the local economy. VET institutions in China gain from this international cooperation with foreign VET by setting up international networks for collaboration. A successful example of this model is the Beijing Transportation and Communication School. Its aim is to provide VET in order to aid the transportation and communication in Beijing and improve the overall economy of the city. The Beijing VET School has been modernised by using a western approach. By collaborating with the Toyota Company from Japan in 1994, the Beijing Transportation and Communication School has made great contributions to the automotive industry in China by providing skilled labour.

\section{The lessons for the VET system in Vietnam}

\subsection{The current linkage between the VET provider and industry in Vietnam}

According to Bünning, Frank, Schnarr, and Alexander (2009), there are three main types of vocational education training delivery. The first type is known as school-based training, in which the French VET system is a good example. The second type is industry-led, and industry sets the standards for the skills required in the workplace. The perfect model of this type is the industry-based training practised in Great Britain. The last type of vocational education delivery involves the combination of two training places (school and industry), of which the dual German system is an example.

Currently, the operation of the Vietnamese VET system resembles the French VET system. It is known as school-based training. There are two main characteristics of this type of system. Firstly, the government has major responsibilities for making all the regulations for the system. The Vietnamese government introduced the Law on Vocational Training in 2006 and this was passed by the National Assembly. However, regarding the relationship between the VET providers and industries, according to the Law on Vocational Training 2006, Chapter 5, Article 55, the government merely encourages this relationship. There are not any policies or detailed mechanisms that specify the rights and responsibilities of each institution. 
Currently, the VET providers only deliver the training programs that were designed using the Developing a Curriculum (DACUM) process which did not involve industry input (Nguyen 2013). This was done under the aegis of the Ministry of Labour, Invalids and Social Affairs (MOLISA). The DACUM process is used to determine the competencies that should be addressed in a training curriculum for a specific occupation. In 2013, MOLISA approved 126 specific occupations at the national level, called National Occupational Skill Standards (NOSS). This demonstrates that the VET providers have driven the skilled human resource market. In other words, the VET schools are the main institutions responsible for producing the skilled workforce for the labour market. The NOSS have many benefits - they assist agencies supplying labour by specifying the skills required of local and foreign workers; and they assist in remuneration decision-making. NOSS also help the training institutions in providing the basis for curriculum development; developing their teaching, learning and assessment resources; assisting in the design of buildings and equipment; and identifying the plant, materials, and equipment for effective training.

However, the main weak point of NOSS is the lack of or limited involvement of industries in designing the curriculum and evaluation in the training process (Nguyen 2013). As result, the VET graduates do not meet the requirements of industries (Hoang 2014). In addition, the industries have not seen much benefit in this cooperative relationship (Mac 2009). In the current situation, industries have the advantage that they benefit from trained employees but have no obligation to contribute in return to the VET providers.

Secondly, the Vietnamese students spend almost all their time in learning and practising at the schools, with practical time in industries amounting to only about $15 \%-25 \%$ of the total. Table 1 summarises the time that advanced diploma level students spend in school and industry. As mentioned, Vietnamese students spend only about $20 \%$ of their time gaining on-site skills in industry. This is in contrast to the situation in France where students are required to spend 50\% of their time in an industrial working environment, and in Germany where they spend three or four days each week working in an industrial environment and only one or two days studying theory in school.

Table1. Time students spend learning and practising in school, and working in industry

\begin{tabular}{lcccc}
\hline \multicolumn{1}{c}{ Units } & Total time (hours) & Theory time & Practical time & Exam time \\
\hline General units (in school) & 450 & 220 & 200 & 30 \\
Professional units (in school) & 2400 & 656 & 1584 & 160 \\
Practical units (in industry) & 640 & 36 & 544 & 60 \\
\hline
\end{tabular}

\subsection{Lessons for Vietnam}

From the examples of the various types of partnership between VET schools and enterprises described above, Vietnamese VET policy makers can learn two important lessons about linkages between the two institutions.

The first lesson concerns the involvement and intervention of the government in orientation, guidance and support through the policies and mechanisms of the cooperation. The examples from Germany (the government legislates on the relationship between two organisations), and South Korea (students and enterprises have contracts based on the policies and mechanisms set by the government) are valuable references for Vietnamese VET policy makers. Interestingly, the link between VET institutions and businesses with the involvement of the government fits in well with the Triple Helix model (Etzkowitz 1993; Leydesdorff 1995). The concept of the Triple Helix model developed out of the shift from a dominating industry-government dyad in the industrial society to a growing triadic relationship between universityindustry-government in the knowledge society, in which industry operates in the Triple Helix as the locus of production; the government as the source of contractual relations that guarantee stable interactions and exchange; and the university as a source of the production of new knowledge and technology.

The second lesson concerns the strong autonomy of VET providers in developing the partnerships with enterprises. All the examples of relationships between VET providers and industries in China are valuable models for the VET policy makers and principals of the VET schools to consider. This means that the heads of VET schools are not only the educators but also have the role of initiating and developing the relationships with industries.

From these two important lessons, four recommendations for Vietnamese VET policy makers, industrial managers, and principals of VET schools emerge. It should be noted that the government has a role as the adjudicator in the orientation, guidance, and support of this cooperation, and the VET schools lead and drive the establishment of the relationships. On the other hand, the role of industries has been seen as the best environment to support students in practising what they have learnt at school.

First, as the referee in the relationship, the government should clearly identify the rights and responsibilities of the state, communities and industries in the vocational education training field. In addition, to support the relationship more effectively, the government should provide more opportunities for VET schools and enterprises to meet to discuss the requirements of each institution. For example, an action that the government can take would be to establish a committee or a forum where representatives from both sides could discuss the current and future needs, and other conditions of the relationship. These committees or forums could be established at both national and local level because the needs and the 
requirements of the two organisations are different at each level. Furthermore, with the agreement of the government, consideration should be given to providing the VET schools with more autonomy in curriculum design. The various approaches in developing partnerships between VET schools and industries in China are useful examples for the heads of VET school to follow.

Second, industries are seen as the most important stakeholders and provide the best opportunities for students to practise in a real-life working environment. Therefore, industries should have a positive attitude and welcome students as genuine workers in the company. The big question is how to nurture a positive attitude among industry leaders and allay their concerns about having students in their workplace. According to Mac, (2009), the solution to this situation is linked to the roles of the government. In this case, the government should clearly identify and point out the rights of and benefits to industrial enterprises, and support them in this linkage by, for example, reducing their tax or granting them land to establish the VET schools inside the enterprises (Law on Vocational Training 2006).

Another important recommendation to industry leaders concerns their role in supplying more information to VET providers about what they require from the skilled workforce. In other words, the industries should point out clearly the job standards, and detail their requirements to VET schools. To achieve, the involvement of industry leaders on the managerial boards of VET schools should be encouraged so that they can contribute to curriculum design and evaluation of the training process (Mori 2013). In addition, there should be open channels of communication between these industry leaders and the VET schools so that the schools can consult quickly and easily with a nominated contact person from the industry side (Mori 2013).

Fourth, two recommendations are proposed to assist the VET providers in establishing effective cooperation. First, the VET providers should initiate the establishment of partnerships with industrial enterprises (the experiences from South Korea and China). According to Rees (2015), "at least, the VET providers have to know what the local businesses need and require". Supporting Rees's view, Cao (2015), the Deputy Director of the General Department of Vocational Training (GDVT), affirmed that making connections between local businesses and vocational schools will be the target of the Vietnamese VET sector in the future. To develop these linkages, the GDVT should consider the relationship between VET providers and industries as one of the requirements in the accreditation framework. Second, the VET schools should improve, enhance and update the training programs with the permission of the government. At the moment, the GDVT allows the VET schools to adjust the curriculum and training programs by up to $30 \%$. However, according to Mori (2013), the VET institutions do not use this opportunity to increase the practical, industry-based component of the curriculum.

\subsection{The model for the linkage between the VET providers and industries}

Considering the Vietnamese context, political issues, the examples, and the discussion on cooperation between VET providers and industries in the previous section, a suitable model is proposed called "school-based apprenticeships". Interestingly, this model fits in well with the model of Nguyen (2013) described in his PhD thesis.

\subsubsection{What is the involvement of the key stakeholders in the model?}

The model is comprised of three components being a combination of secondary school subjects, paid work, and vocational education training undertaken on the job. There are four key stakeholders involved in this model. The first key stakeholder is the students who will enter the VET programmes. The apprentice/trainee must obtain at least a year 9 certificate (Education Law, 2009). This means that any student who has passed year 9, 10, 11 or 12 would be eligible to apply. The second key stakeholder is the VET providers who provide both secondary subjects and the vocational education training. The third key stakeholder is the industries that provide the workplace for the students to practise, to work and get paid through the contract they have with the students. The fourth key stakeholder is the government, represented by Ministry of Labour Invalid Social Affair (MOLISA). MOLISA is responsible for providing information and support to apprentices, trainees, and employers regarding all aspects of the apprenticeship or traineeship including incentives available. Table 2 describes the current model of the relationship between VET providers and industries, and the proposed model.

\subsubsection{The benefits of this model}

The main reason this model is proposed is because it has been shown to meet the requirements of students, community, and industries. On the student side, this model not only provides opportunities to enter the VET sector for lower secondary student graduates, students who have completed year 10, 11 and 12, but also provides work experience in industries. In other words, it offers real flexibility and variety (Queensland Government 2015). The secondary students comprising of lower secondary graduates (year 9), students year 10,11 and 12 who enrol in the VET sector firstly have an opportunity to get the Higher School Certificate and secondly to attain a nationally recognised Vocational Education and Training (VET) qualification. In addition, they gain valuable work skills and experience and get paid through their contract with industries. After completion of the VET program, students have the choice of immediate employment or entering the higher education pathway. 
Table2. Current and proposed model of the relationship between VET providers and industries

\begin{tabular}{ll}
\hline \multicolumn{1}{c}{ Current model } & \multicolumn{1}{c}{ Proposed model } \\
\hline $\begin{array}{l}\text { The school-driven mode that offers the currently } \\
\text { available programmes }\end{array}$ & $\begin{array}{l}\text { The industry-driven mode that offers services and } \\
\text { meets the requirements of the labour market and } \\
\text { industries. }\end{array}$ \\
$\begin{array}{l}\text { The training curriculum is fixed with limited } \\
\text { involvement of industries in the design of curriculum. }\end{array}$ & $\begin{array}{l}\text { The training curriculum is flexible with the strong } \\
\text { involvement of industries in the design and } \\
\text { evaluation. }\end{array}$ \\
Graduated student seeks a job by himself or herself. & $\begin{array}{l}\text { Students sign a contract with the employer. } \\
\text { A decentralised, flexible and diversified VET system } \\
\text { The role of government is centralised and inflexible. }\end{array}$ \\
Industry stands outside of the training process. & \begin{tabular}{l} 
Industry is a part of the training process. \\
\hline
\end{tabular}
\end{tabular}

This model also contributes to the community. Employers who take on school-based apprentices can make a real difference by motivating young people to work towards their future goals and giving them realistic exposure to their industry or sector.

In addition, this model is very satisfactory for the employers and the industry leaders. Employers and supervisors often experience a great deal of satisfaction with the process as they help individuals mould new skills and gain confidence in a work environment. There is confidence that once students have left school, they will meet the requirements of their employers.

\subsubsection{The challenges}

However, there are two main challenges for the VET sector in putting this model into practice. First, the model of school-based or school-driven training has been entrenched in the VET sector since it was established in 1969. Thus it is ingrained in the perception of all classes of society. The shift from the school-driven model to the industrial-led model requires not only the involvement of the government but also the positive support of industries. This shift will also require the VET providers to take the initiative in developing partnerships with industries. Second, the VET sector is negatively perceived by students, parents and industry. With the concerted efforts of the government and significant investment in the sector, it is vital that the image of the sector is improved. A campaign to market the sector needs to emphasize the fundamental reforms proposed.

\section{Conclusion}

In summary, this conceptual paper on the terms of the strategic partnership; the factors that enhance or constrain the linkage between VET providers and industry; and the various models of partnerships in five countries provide a range of experiences. Vietnamese VET policy makers can learn from these models and adopt elements of them as they deem appropriate. However, it is important that the school-business collaboration does not become dominated by one of the partners, the government, schools, or industry, each of which may run independent of one another or alternate in value during the relationship stages.

The government takes importance because of its managing, planning and coordinating duties. The government provides financial resources and gives merit to legal cooperative action.

The school takes importance because of its role in implementing training programs and providing enterprise specific services, it carries out school run enterprises that focus on teaching and production.

The industry takes importance for beginning the collaboration and by utilizing the resources available to VET schools, helps to produce quality outcomes.

\section{References}

Atchoarena, D. (1999). Getting the stakeholders involved: Partnership at work in three countries from Africa, Asia and Eastern Europe. Paris: UNESCO/IIEP.

Bünning, Frank, Schnarr, \& Alexander. (2009). Forging Strategic Partnerships between Stakeholders in TVET Implications for the Vietnamese Vocational Education and Training System. Retrieved from http://www.unevoc.unesco.org/up/Link_Voc_End.pdf

Education Law (2009). LUẬT GIÁO DỤC. Retrieved from http://hcstranquoctuanhoavang.edu.vn/uploads/laws/luatgiao-duc-hopnhat-2009.pdf

Etzkowitz, H., \& Leydesdorff, L. (2000). The dynamics of innovation: From National Systems and "Mode 2" to a Triple Helix of university - industry - government relations. Research Policy, 29(2), 109-123. 
Hoang, N.V. (2014). Giáo dục nghề nghiệp: Chưa hêt nhức nhối. Retrieved from

http://www.daidoanket.vn/PrintPreview.aspx?ID=95698

Mitchell, A. (1998): Strategic training partnerships between the State and enterprises. Geneva: International Labour Office.

Mac, V.T. (2009). The Situation of Vocational Training and the Linkage between Vocational Training and Enterprises in Vietnam. Retrieved from http://www.unevoc.unesco.org/up/Link_Voc_End.pdf

Mori, J. (2014). Thúc đẩy mối quan hệ đối tác ba bên để giải quyết sự khập khiễng kỹ năng: Các chiến lược phát triển kỹ năng đổi mới để đẩy nhanh sự nghiệp công nghiệp hóa của Việt Nam. Retrieved from

http://www.jica.go.jp/vietnam/english/office/others/c8h0vm00008ze15n-att/policy_paper_vn.pdf

Nguyen, C.T. (2013). Analysis of factors influencing to vocational education training in Vietnam: Implication for improving its quality period 2013-2020. PhD Dissertation: Thai Nguyen University.

Rees, A. (2015). "Lối thoát" cho đào tạo nghề. Retrieved from http://dantri.com.vn/viec-lam/loi-thoat-cho-daotaonghe1085348.htm

Queensland Government, (2015). Advantages of school-based apprenticeships and traineeships. Retrieved from http://apprenticeshipsinfo.qld.gov.au/school-based/advantages/

Wu, Q. (2009). Linkages between Vocational Education and Industry in China -The Current Environment. Retrieved from http://www.unevoc.unesco.org/up/Link_Voc_End.pdf 